\title{
Surgical Studies of Reconstructive Breast Surgery - An Overview of the Topics at the 2019 Annual Meeting of the Working Group for Reconstructive Surgery in Oncology-Gynecology
}

\author{
Operative Studien in der rekonstruktiven Mammachirurgie - \\ ein Beitrag von der Jahrestagung der Arbeitsgemeinschaft \\ Wiederherstellende Onkologie in der Gynäkologie 2019
}

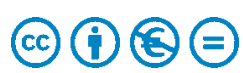

Authors

Stefan Paepke ${ }^{1}$, Marion Kiechle ${ }^{1}$, Christine Ankel ${ }^{2}$, Joy Weyrich ${ }^{1}$, Evelyn Klein ${ }^{1}$, Anna Schneider ${ }^{1}$, Navid Johannigmann-Malek ${ }^{3}$, Anna-Sophia Dietrich ${ }^{1}$, Ralf Ohlinger ${ }^{4}$, Marc Thill ${ }^{5}$

Affiliations

1 Klinik und Poliklinik für Frauenheilkunde, Klinikum rechts der Isar der Technischen Universität München, München, Germany

2 Rotkreuzklinikum München, München, Germany

3 Klinikum rechts der Isar der Technischen Universitat München, München, Germany

4 Gynaecology and Obstetrics, Universitatsmedizin Greifswald, Greifswald, Germany

5 Klinik für Gynäkologie und Geburtshilfe, Interdisziplinäres Brustzentrum, Agaplesion Markus Krankenhaus Frankfurt am Main, Frankfurt am Main, Germany

Key words

reconstructive breast surgery, implant position, application safety

Schlüsselwörter

rekonstruktive Mammachirurgie, Implantatlage, Anwendungssicherheit

received 27.2.2019

accepted 12.3.2019

Bibliography

DOI https://doi.org/10.1055/a-0873-8110

Geburtsh Frauenheilk 2019; 79: 584-590 @ Georg Thieme

Verlag KG Stuttgart · New York | ISSN 0016-5751

\section{Correspondence}

Dr. Stefan Paepke

Leiter des Interdisziplinären Brustzentrums der Frauenklinik, Klinikum rechts der Isar der Technischen Universität München, Comprehensive Cancer Center Munich Ismaninger Straße 22, 81675 München, Germany stefan.paepke@mri.tum.de
Deutsche Version unter:

https://doi.org/10.1055/a-0873-8110

\section{ABSTRACT}

This year's annual AWOgyn meeting focused on studies of reconstructive breast surgery. As the majority of breast reconstructions are implant-based, most studies also focused on implant-based reconstruction. Since 2011, the guidelines have recommended using interposed mesh materials as support. The basic idea behind every type of material is to provide coverage and stabilization for the implant by constructing an "internal bra" which will create the appropriate implant shape and maintain the position, stability and flexibility of the implant. The Working Group for Reconstructive Surgery in Oncology-Gynecology (AWOgyn) has undertaken to analyze different materials with regard to indications, success rates and side effects as documented in registers, clinical assessments and study protocols. This has increased application safety and is expected to improve it even further in future. Prospective studies are being carried out to investigate issues such as the optimal material, optimal implant site and best cosmetic results. The first results for porcine and human acellular matrices and for partially resorbable titanium-coated synthetic polypropylene meshes are now available. In 2019, the AWOgyn working group will be launching further studies to evaluate a perforated acellular dermal matrix $\left(\right.$ Fortiva $\left.^{\circledR}\right)$, a titaniumcoated implant pocket (TiLOOP ${ }^{\circledR}$ Bra Pocket) and a fully resorbable synthetic mesh (TIGR ${ }^{\circledR}$ mesh).

\section{ZUSAMMENFASSUNG}

In der diesjährigen AWOgyn-Tagung wurde die Studienlandschaft der rekonstruktiven Mammachirurgie beleuchtet. Da die Mehrzahl der Brustrekonstruktionen implantatbasiert durchgeführt wird, liegt hier auch der Fokus der Studienaktivitäten. Seit 2011 wird die Verwendung von unterstützenden 
und interponierenden Netzmaterialien in den AGO-Leitlinien empfohlen. Die Idee hinter allen Materialien besteht in der Bedeckung und Stabilisierung des Implantats durch Bildung eines inneren $\mathrm{BH}$ und der damit zu erreichenden Form- und Positionsstabilität des Implantats. Die Arbeitsgemeinschaft Wiederherstellende Onkologie in der Gynäkologie (AWOgyn) hat sich zum Ziel gesetzt, die unterschiedlichen Materialien in ihren Indikationen, Erfolgsraten und Nebenwirkungen in Registern und klinischen Untersuchungen sowie in Studienprotokollen zu analysieren. Dadurch wurde und wird die Anwendungssicherheit insgesamt deutlich erhöht werden. Durch prospek- tive Untersuchungen werden die Fragen nach dem optimalen Material, der optimalen Implantatlage und dem besten kosmetischen Ergebnis prospektiv untersucht. Zu porcinen und humanen azellulären dermalen Matrices, zu teilresorbierbaren und titanisierten synthetischen Polypropylennetzen liegen erste Daten vor. 2019 werden weitere Studien, die eine perforierte azelluläre dermale Matrix (Fortiva ${ }^{\circledR}$ ), die titanisierte Implantattasche (TiLOOP ${ }^{\circledR}$ Bra Pocket) und ein voll resorbierbares synthetisches Netz (TIGR ${ }^{\circledR}$ mesh) bewerten, im Rahmen der AWOgyn-Studienarbeit initiiert.

\section{Introductory Comments}

A wide range of current treatment concepts, international cooperations, ongoing and planned studies were presented and discussed at this year's annual AWOgyn meeting.

Before moving on to the presentation of different trials, the meeting began by considering a few basic issues in reconstructive breast surgery:

- the indications and decision-making algorithms for autologous or heterologous reconstruction

- the need for and conditions required when using supporting, interposed and implant-covering foreign materials

- the areas of application and indications for biological matrices and synthetic meshes

- the importance of integrating foreign materials in the implant capsule

- the importance of resorption and dissolution of synthetic materials as part of the process of tissue ingrowth and integration in the implant capsule

- the decision-making algorithm for the optimal implant site (pre-pectoral or subpectoral)

- the evaluation of different reconstructive methods by surgeons and patients (Patient Reported Outcome) [1,2]

- the long-term outcomes of different reconstruction procedures

\section{Reconstructive Treatment Methods - from Innovative to Standard}

In breast surgery, surgical planning is increasingly taking the form of "targeted surgery" (terminology from M. Rezai) [3]. The options for breast-conserving procedures have been considerably expanded by the downstaging of tumor sizes following primary systemic treatment and by the range of oncoplastic surgical techniques. This is borne out by the fact that the rate of breast-conserving surgery in recent years has consistently been well above $70 \%$. On the other hand, there has also been a significant increase in primary, secondary and prophylactic bilateral and contralateral mastectomies [4]. The defined target is the removal of all breast gland tissue to obtain the expected risk reduction. Extensive data have confirmed that subcutaneous skin-sparing mastectomy with preservation of the nipple-areola complex (NAC) (nipple-sparing mastectomy, NSM) is a safe and esthetically acceptable surgical option [5-9]. If the procedure is anatomically precise, the same amount of breast gland tissue will remain in situ following NSM as after modified radical mastectomy (MRM) procedures (approx. $1.4 \%, 1-3 \%$ ) with an equivalent rate of central and peripheral local recurrence. For many patients who wish to have a breast reconstruction this will allow the skin covering to be preserved, thereby providing the basic anatomical conditions for cosmetic breast reconstruction $[10,11]$. The remaining skin cover can ultimately be filled using autologous fat tissue (DIEP, TRAM, FCI, S-GAP) or by an implant supported by a mesh or matrix.

\section{Implant-based plastic and reconstructive breast surgery}

Around $40-60 \%$ of all breast reconstructions carried out in Europe and around $75 \%$ of all breast reconstructions done in the USA use implant-based techniques [12-14]. Because of this, it is understandable that the focus is on these techniques and on the best means of covering the implant and shaping the reconstructed breast $[15,16]$. A number of foreign materials are available, and the first use of these materials was already described by Brunnert and Warm in 2008 [17]. Since then, numerous synthetic meshes with different levels of resorbability and various biological matrices of varying provenance, thickness, consistency and foldability have become available. How these different meshes and matrices are used in different countries and for which indications is unclear, not least because the available data about the different materials is insufficient [18]. The basic goal with all materials is that they cover and stabilize the implant by creating an "internal bra" which will ensure a consistent shape and position of the implant. Both groups of materials provide an esthetically pleasing implant capsule structure once they have integrated into the tissue, with a smooth inner capsule surface and optimal coverage of the implant [19-27].

The Working Group for Reconstructive Surgery in OncologyGynecology (AWOgyn) has set itself the goal of analyzing the different materials used in reconstructive breast surgery, based on the indications, success rates and side effects reported in registers, clinical trials and study protocols. This has helped to significantly improve overall application safety and will continue to improve it in future as well. As mentioned above, the first evaluations were carried out by Brunnert and Warm in 2008 [17]; in the years thereafter, retrospective analyses with different case numbers 
have been presented for different materials, but the data provided was merely satisfactory without reaching a higher level of evidence [28-34]. Although most recent literature includes reviews and meta-analyses, these do not provide conclusive results because of the generally retrospective nature of the evaluated data and the heterogeneity of indications and surgical techniques [35]. Although the data obtained were again only retrospective, the multicenter data analysis by Dieterich et al. is the first to provide an indirect comparison of titanium-covered polypropylene meshes with other materials using larger numbers of cases [36].

Over time, subpectoral implant placement has become the standard method for implant-based reconstruction, either with

- skin coverage alone (at least as an interim solution until definitive reconstruction),

- complete muscle coverage,

- a dual-plane method with a de-epithelized corium flap,

- caudolateral interpolation of an acellular matrix,

- caudolateral interpolation of a synthetic mesh,

- a combination of these techniques.

The types and rates of complications have been described in many analyses, although the majority of these studies were retrospective [37]. The few existing prospective studies largely support the findings of the retrospective analyses. In summary, it was found that both synthetic meshes and acellular dermal and tissue matrices can be considered as safe [38-40]. The use of synthetic meshes appears to be associated with fewer complications in terms of seroma formation or implant loss. Only a single prospective directly comparative study reported a better outcome with a titanium-covered polypropylene mesh (TiLOOP ${ }^{\circledR}$ Bra) compared to acellular dermal matrices (ADM) in terms of both complication rates and cosmetic results [41]. The first applications of recently developed dermal matrices have been shown to have lower rates of side effects and will be analyzed further in various studies and registers.

In addition to the question regarding the best type of material to use another highly important issue is where the best implant site is: pre- or subpectoral?

The standard use of a subpectoral implant site ( $\bullet$ Fig. $\mathbf{1}$ ) is associated with many significant problems, such as:

- an unnatural breast shape

- the "jumping breast" phenomenon

- an accompanying movement of muscles, even during non-expansive movements

- muscle pain

- contraction of the upper exterior part of the severed pectoralis major muscle with wrinkling below the muscle origin

- fasciculations

- restricted shoulder-arm mobility

\section{What Now?}

\section{Implant site: subpectoral versus pre-pectoral}

Sigalove et al. recently reported on 207 patients operated on since 2008 who underwent pre-pectoral implant placement, ADM coverage and lipofilling (bioengineered breast concept) in

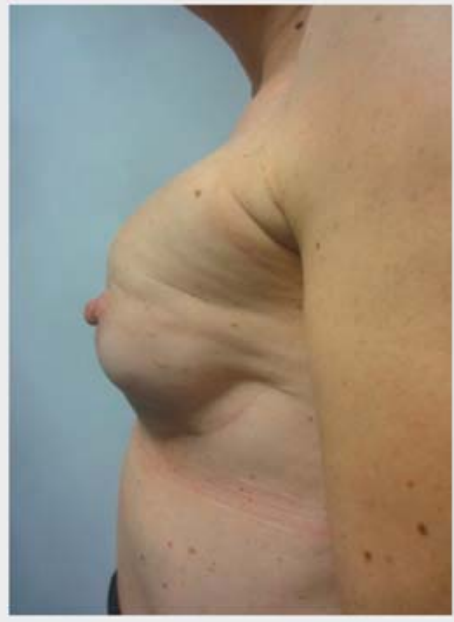

- Fig. 1 A 34-year-old patient at 7 months after subcutaneous mastectomy (s/p primary chemotherapy, s/p radiotherapy). She underwent immediate reconstruction with subpectoral implant placement and caudal mesh interpolation. Currently affected by jumping-breast phenomena, capsular fibrosis $\mathrm{II}^{\circ}$, cranialization of the implant and volume loss in the caudal quadrants.

353 operations. The rate of complications was remarkably low. The infection rate was $4.5 \%$, with seroma formation occurring in only $2 \%$ of cases and flap necrosis in only $2.5 \%$ of cases [42].

In recent years, pre-pectoral implant sites have begun to be used more widely again in German-speaking countries, as confirmed by the publication of a number of case studies, case series and retrospective analyses [43]. During a free lecture session at last year's DGS conference, Reitsamer et al. described a surgical procedure consisting of pre-pectoral implant placement with complete implant coverage using a porcine ADM $[44,45]$. It has been suggested that pre-pectoral implant placement using an ADM has the benefit of providing tissue support. Different manufacturers have responded to the particular requirements of prepectoral implant sites by developing new shapes. Pre-shaped ADM materials include Braxon (Decomed Srl, Italy), used in this case directly as an implant pocket, and other ADMs such as Tutomesh, Fortiva, Strattice or the contoured shapes of Artia [46].

New materials have also been developed for synthetic meshes. Based on the experiences of Cassella et al. and Rezai, a pre-shaped implant pocket made of titanium-covered polypropylene has been developed which makes pre-pectoral implant positioning with complete titanium mesh coverage significantly easier ( Fig. 2) [47, 48].

Three different implant pockets with increasing implant volumes of $<270$; $<420$ and $<550 \mathrm{~cm}^{3}$, implant widths ranging from 11.0 to $15.0 \mathrm{~cm}$ and projections of $<4.5$ to $<6.0 \mathrm{~cm}$ are available. The TiLOOP ${ }^{\circledR}$ Bra Pocket is already in frequent use in Italy and has now been used in around 450 applications in different breast centers across Germany ( $\bullet$ Fig. $\mathbf{3 a - c}$ ). 


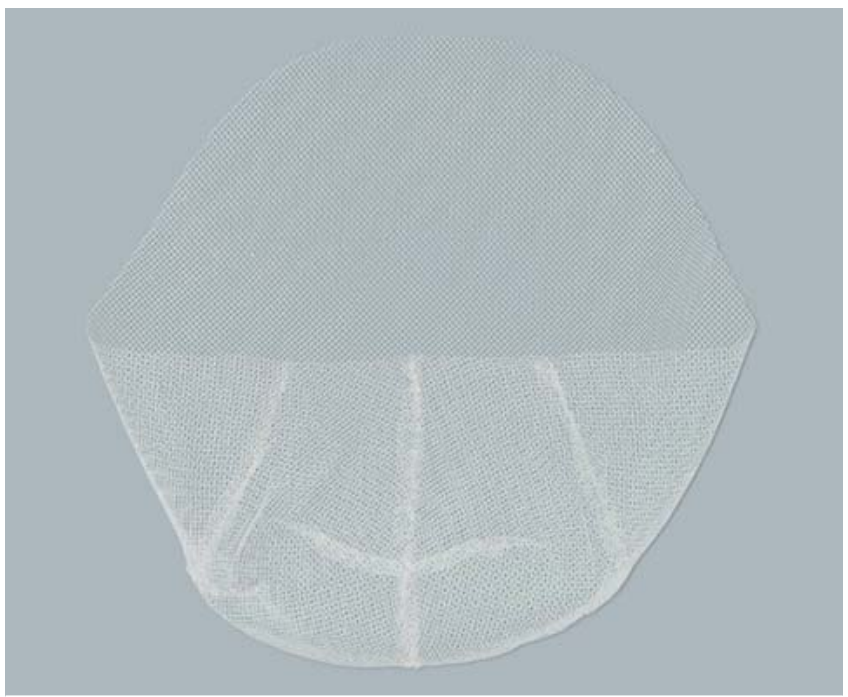

- Fig. 2 Synthetic mesh developed especially for pre-pectoral implant placement (TiLOOP ${ }^{\circledR}$ Bra Pocket).

\section{Studies by AWOgyn}

Most recently, AWOgyn has focused on creating a comprehensive register of all implant-based reconstructions. Different multicenter studies have also been carried out, and their results will be discussed and published in the near future. The initial results of the NOGGO/AWOgyn trial on the use of the human ADM Epiflex ${ }^{\circledR}$ have already been presented at this year's senology congress [2]. A survey carried out by AWOgyn at breast centers in Germany found that 81 clinics would be prepared to participate in surgical studies.

AWOgyn has launched several study projects to address questions such as what is the best implant site and what is the best coverage material, based on each individual patient's respective situation:

1. Development of a decision-making algorithm for subpectoral or pre-pectoral implant placement.

The decision for a specific implant position is affected by numerous factors which have not yet been compared and rated. A consensus process was used to compile factors (patient history, lifestyle, tumor parameters, habitual factors, soft tissue thickness and other factors) which could be combined into a decision-making algorithm. The algorithm will be tested to determine its practical applicability.

2. Use of a newly developed, thin, easily foldable, perforated, porcine, acellular dermal matrix (Fortiva 1.0) ( $\triangleright$ Fig. 4) in reconstructive breast surgery.

This prospective study will be carried out in 5 centers. The plan is to recruit 100 patients to evaluate such basic issues as the most appropriate material, the indications, and the impact of perforation on the rate of complications as well as mediumterm complications and outcomes.

3. Use of a pocket made of titanium-coasted polypropylene which was specially developed for pre-pectoral implant placement ( Fig. 2).

Following the PRO-BRA study which collected patient-reported-outcome data and investigated the ultimate shape created by the use of a titanium-coated polypropylene mesh pocket, the pre-pectoral use of this pocket will be prospectively evaluated in 350 patients treated at 10 centers in Ger-
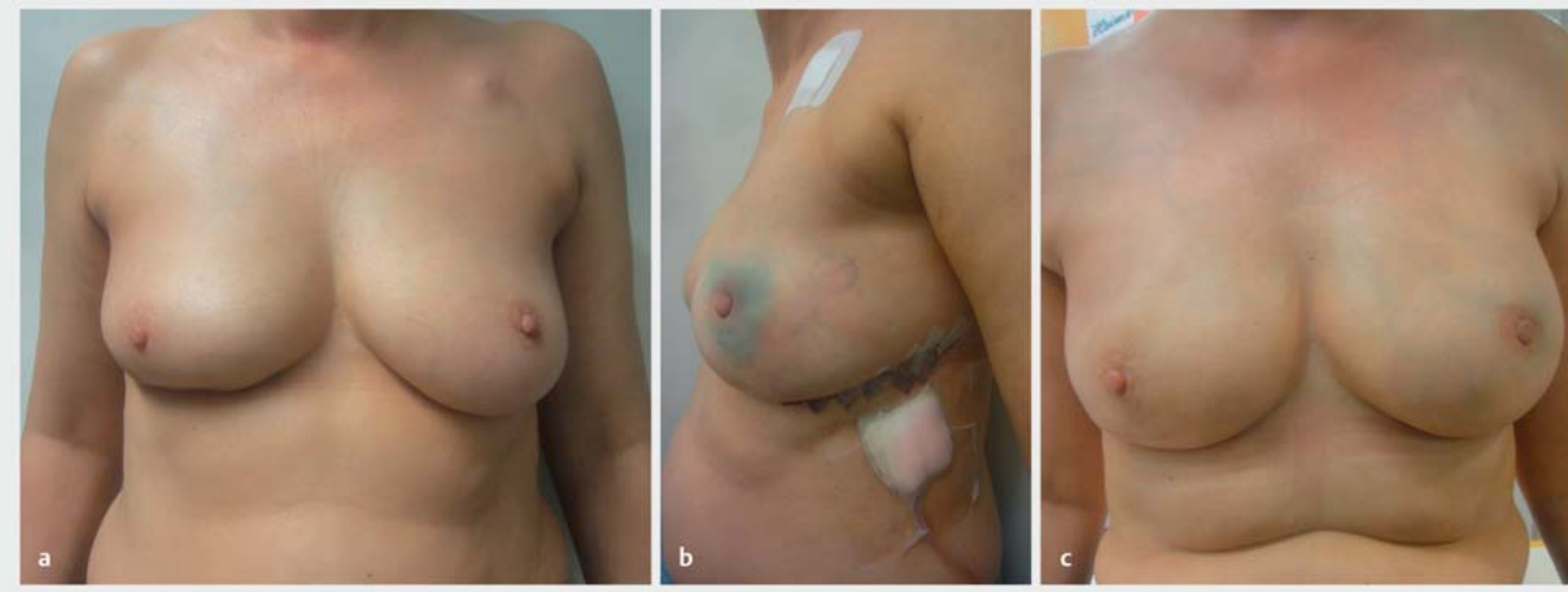

- Fig. 3 A 53-year-old patient, s/p right-sided breast cancer, segmental resection, SLNB in 2015 for luminal B breast cancer subtype, adjuvant chemotherapy and radiotherapy, and s/p contralateral left-sided TNBC, PALB2 mutation, primary systemic chemotherapy, recent bilateral subcutaneous, nipple-sparing mastectomy and SLNB on the left side and port removal. The patient underwent immediate reconstruction with pre-pectoral implant placement and medium coverage with a TiLOOP ${ }^{\circledR}$ Bra Pocket. a Preoperative image, b on the 4th postoperative day, $\mathrm{c}$ at 8 weeks postoperatively. 


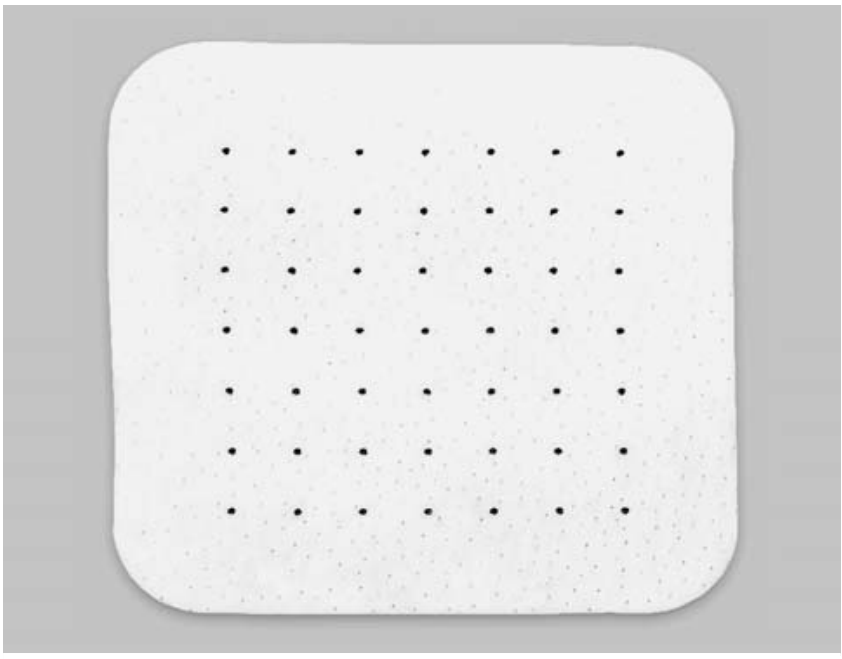

- Fig. 4 Fortiva - perforated porcine acellular dermal matrix.

many and Austria with a follow-up period of 36 months. The survey will use the Breast-Q quality-of-life questionnaire.

4. Use of a fully resorbable synthetic mesh for pre-pectoral implant placement (• Fig. 5).

Another study concept will be looking at a similar issue, the question of the optimal implant coverage for pre-pectoral implants using a completely resorbable synthetic mesh (TIGR mesh, Novus Scientific, Sweden). There is, as yet, no clear answer to the question whether complete resorption offers a (measurable) benefit compared to non-resorbable or only partially resorbable materials. The focus here will be primarily on the long-term outcomes including the rate of re-operation and the capsular fibrosis rates. A total of 130 patients are being evaluated in an AWOgyn/NOGGO project with a follow-up of 36 months.

The use of the porcine acellular dermal matrix $\operatorname{Artia}^{\circledR}$, the latest Strattice ${ }^{\mathrm{TM}}$ tissue matrices, changes in the shape, material thickness and foldability will be evaluated based on data from registries. In 2017, the PRO-BRA study completed its recruitment of 271 patients. The study evaluated the use of the titanium-coated polypropylene mesh TiLOOP ${ }^{\circledR}$ Bra using patient quality of life as measured by the Breast-Q questionnaire as its primary endpoint. The follow-up period for this study has been extended from 24 to 48 months. This means that the first prospective long-term data will be available in 2020 .

\section{Outlook}

Up to now, the basic strategies for reconstructive breast surgery were developed based on individual experiences and retrospective analyses. However, in recent years, the number of prospective studies and the amount of data in registers have increased substantially, and this is reflected by the levels of evidence underpinning AGO treatment recommendations. Prospective studies investigating partially resorbable and non-resorbable synthetic meshes and human, and bovine and porcine ADMs with regard

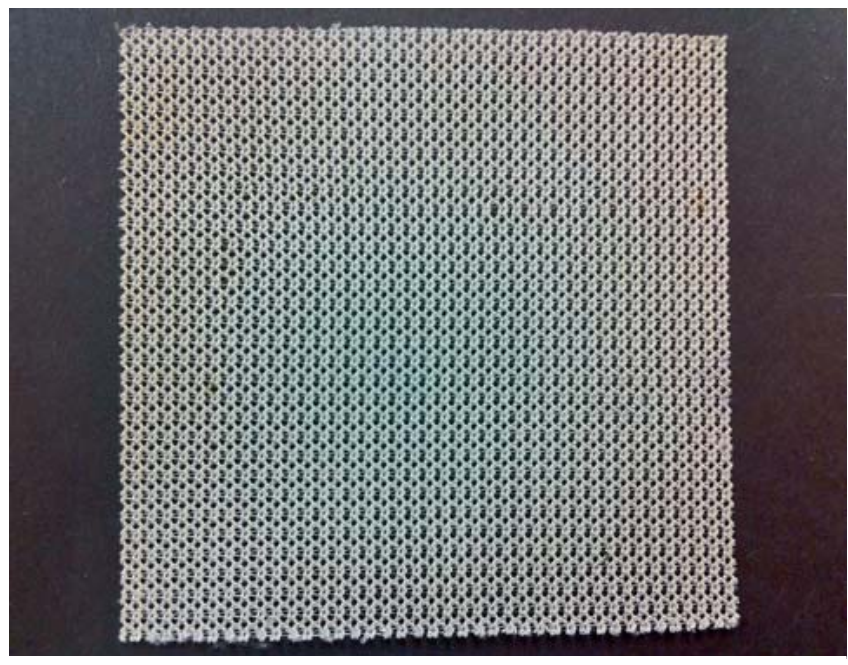

- Fig. 5 Completely resorbable synthetic TIGR mesh.

to complications and esthetic results have been presented and published. Patient satisfaction rates of $80-90 \%$ with regard to cosmetic appearance have been achieved together with acceptable complication rates $[2,49]$.

Nevertheless, the focus is still on optimizing autologous and implant-based reconstructive surgical techniques. Deciding on the appropriate implant site based on the individual plans for surgery has become significantly easier following the development of new and improved materials; the parameters are entered into algorithms, and the indications and complications are analyzed in prospective studies.

The studies presented here were discussed, leading to suggestions about what an optimal scientific scenario could look like. The ideal scenario would naturally be prospective, randomized studies with very large numbers of patients and long follow-up times. But, realistically, it is clear that the limited resources and the fast pace of developments in the overall market create significant barriers.

Overall, the general consensus was that the current trend of carrying out rapid, targeted studies under the aegis of AWOgyn which focus on partial aspects and unresolved issues and come up with concrete answers within a short space of time is very positive. This approach should help us to piece the full picture together, bit by bit, in the coming years.

\section{Acknowledgements}

We would like to thank all of our colleagues whose different activities made the ongoing projects possible, our $\mathrm{PhD}$ students for their valuable hard work, the surgeons for their documentation, and AWOgyn for creating a program structure for the studies and for its continued support.

\section{Conflict of Interest}

Financial disclosure: Paepke S, Ankel C, Thill M and Ohlinger R have disclosed all financial benefits received (honoraria, financial support for clinical projects and for educational and advanced training events and funding of travel costs). Klein E, Weyrich J, Johannigmann A, Dietrich AS did not disclose any financial benefits. 


\section{References}

[1] Paepke S. Präpektorale Implantateinlage in der plastisch-rekonstruktiven Mammachirurgie unter Verwendung des TiLOOP ${ }^{\circledR}$ Bra Pocket. Senologie 2018; 15: e36-e37. doi:10.1055/s-0038-16516774

[2] Blohmer JU. Prospektive multizentrische nicht-interventionellen AWOGyn-NOGGO Intergroupstudie mit Epiflex ${ }^{\circledR}$ in der Brustrekonstruktion. Senologie 2018; 15: e3. doi:10.1055/s-0038-1651677

[3] Rezai M, Kern P. Neue operative Methoden der Brustchirurgie. Probleme und Lösungen. J Ästhet Chir 2012; 5: 29-36

[4] Downes KJ, Glatt BS, Kanchwala SK et al. Skin-sparing mastectomy and immediate reconstruction is an acceptable treatment option for patients with high-risk breast carcinoma. Cancer 2005; 103: 906-913

[5] Paepke S, Schmid R, Fleckner $S$ et al. Subcutaneous mastectomy with conservation of the nipple-areola-skin: broadening the indications. Ann Surg 2009; 250: 288-292

[6] Gerber B, Krause A, Dieterich M et al. The oncological safety of skin sparing mastectomy with conservation of the nipple areola complex and autologous reconstruction: an extended follow-up study. Ann Surg 2009; 249: 461-468

[7] Carlson GW, Bostwick J, Styblo TM et al. Skin-sparing mastectomy. Oncologic and reconstructive considerations. Ann Surg 1997; 225: 570575

[8] Carlson GW, Styblo TM, Lyles RH et al. Local recurrence after skin-sparing mastectomy: tumor biology or surgical conservatism? Ann Surg Oncol 2003; 10: 108-112

[9] Glöggler A. Operative Therapie des Mammakarzinoms unter onkologischen Aspekten. 22.03.2012. Online: http://www.ago-online.de/ fileadmin/downloads/leitlinien/mamma/maerz2012/07_2012D_ Operative_Therapie_des_Mammakarzinoms_unter_onkologischen_ Aspekten.pdf; last access: 27.08.2012

[10] Niemeyer M, Ettl J, Plattner B et al. Extended indications for skin conservation of the nipple areola complex during subcutaneous mastectomy. Arch Gynecol Obstet 2010; 282 (Suppl. 1): 3-62 (\#43)

[11] Niemeyer M, Paepke S, Niemeyer B et al. Mamillen erhaltende Mastektomie - Ist die Fokussierung auf eine verbesserte Kosmetik in Bezug auf die onkologische Sicherheit vertretbar? Senologie 2011; 8: A141

[12] American Society of Plastic Surgeons. Plastic Surgery Statistics Report 2015. Online: https://www.plasticsurgery.org/news/plastic-surgerystatistics; last access: 13.11.2016

[13] Serletti JM, Fosnot J, Nelson JA et al. Breast reconstruction after breast cancer. Plast Reconstr Surg 2011; 127: 124e-135e

[14] Albernoz CR, Bach PB, Mehrars BJ. A paradigm shift in U.S. breast reconstruction increasing implant rates. Plast Reconstr Surg 2013; 131: 15-23

[15] Davies K, Allan L, Roblin P et al. Factors affecting post-operative complications following skin sparing mastectomy with immediate breast reconstruction. Breast 2011; 20: 21-25

[16] Dian D, Anthuber C, Bauerfeind I, Beyreuther HJ, Braun M, Bubb CF, De Waal JC, Drinova V, Edler von Koch F, Engel J, Gabka C, Hamann U, Heitmann C, Himsl I, Kaiser C, Kolben M, Löhrs B, Mosner M, Paepke S, Schwoerer M, Taskov C, Weiß E, Widschwendtner P. Operative Therapie des primären Mammakarzinoms und Rekonstruktionsverfahren. In: Bauerfeind I; Projektgruppe Mammakarzinom; Tumorregister München, Hrsg. Manual Mammakarzinome. Empfehlungen zur Diagnostik, Therapie und Nachsorge. 13. Aufl. Stuttgart: Thieme; 2011: 121-127

[17] Brunnert K, Warm M. Technik der Gewebeexpansion in der plastischen Chirurgie. Gynäkol Praxis 2008; 32: 479-493

[18] Dieterich M, Faridi A. Biological matrices and synthetic meshes used in implant-based breast reconstruction - a review of products available in Germany. Geburtsh Frauenheilk 2013; 73: 1100-1106
[19] Paepke S, Bronger H, Paepke D et al. Titanised mesh supported immediate reconstruction after subcutaneous nipple-areola-complex conserving mastectomy - First experiences with the TiLoopBra ${ }^{\circledR}$. Rev SenologiaPatol Mam 2010; 23 (Suppl. 1): 163210 (\#170)

[20] Paepke S, Dittmer S, Rezai A et al. Subpectoral implants in oncoplasticreconstructive breast surgery: Habit or necessity? Eur J Cancer 2012; 8 (Suppl. 1): 212

[21] Paepke S, Klein E, Ettl J et al. Nipple Sparing Subcutaneous Mastectomy (NSSM) as Dual-plane Prosthetic Reconstruction Using the Modified Wise Pattern Mastectomy, Fasciocutaneous Flap and TitanPolypropylene-Mesh-Interponation in Women with Macromastia. Eur J Cancer 2012; 8 (Suppl. 1): 212

[22] Paepke S, Klein E, Ettl J et al. Systematik der TiLoopBra ${ }^{\circledR}$-gestützten gewebeinterponierenden Operationstechniken i.R. der plastisch-rekonstruktiven Mammachirurgie. Senologie 2011; 8: A145

[23] Paepke S, Müller D, Paepke D et al. Aktuelle Aspekte in der operativen und plastisch-rekonstruktiven Mammachirurgie. Journal Onkologie 2009; 5: 248-250

[24] Paepke S, Niemeyer M, Krol J et al. Erfahrungen mit dem Einsatz eines titanisierten Polypropylennetzes in der onkoplastischen Brustchirurgie. PraktischeGynäkologiegyn 2010; 15: 150-156

[25] Perabó M, Bodungen V, Drinovac V et al. Brustaufbau mit Schweinehautmatrix. Geburtsh Frauenheilk 2011; 71: 7-9

[26] Spear SL, Seruya M, Clemens MW et al. Acellular dermal matrix for treatment and prevention of implant associated breast deformities. Plast Reconstr Surg 2010; 127: 1047-1057

[27] Spies M. Der Einsatz von regenerativen Gewebeersatzmaterialien in der plastischen Chirurgie. Plastische Chirurgie 2009; 2: 91-94

[28] Dittmer S, Paepke S, Klein E et al. First experience with the implementation of a two component polypropylene Vicryl-mesh (SeragynBr ${ }^{\circledR}$ ) as tissue-supporting extraneous material in plastic reconstructive surgery. Eur J Cancer 2012; 8 (Suppl. 1): 224

[29] Harms E. Application and biological behavior of a partial resorbable alloplastic breast surgery. Vortrag auf der Jahrestagung der russisch deutschen Gesellschaft für Frauenheilkunde 2011

[30] Hill U, Jentschke M, Soergel P et al. Erste Erfahrungen mit azellulärer porciner dermaler Matrik in der rekonstruktiven Brustchirurgie mit Implantaten. Senologie 2012; 9: 106-110

[31] Kiechle M, Klein E, Paepke D et al. Use of scellular dermis (Strattice TM) in problematic cases of breast reconstructive surgery. Eur J Cancer 2012; 8 (Suppl. 1): 177

[32] Klein E, Kiechle M, Ettl J et al. TiLoopBra ${ }^{\circledR}$ als Gewebeinterponat bei subkutaner Mamillen-Areola-Komplex erhaltender Mastektomie (NSSM) Strategiewechsel von Mehr- zu Einschrittoperationen und retrospektive Datenerhebung. Senologie 2011; 8: A105

[33] Klein E, Kiechle M, Ettl J et al. Analysis of immediate breast reconstruction with the use of titanized polypropylene mesh (TiloopBra ${ }^{\circledR}$ ). Eur J Cancer 2012; 8 (Suppl. 1): 224

[34] Nestle-Krämling C. Brustrekonstruktion. Verbesserte Möglichkeiten nach Sofortrekonstruktion mit Implantaten durch Biomaterial. Forum Sanitas 2010; 1: 33-35

[35] Cook LJ, Kovacs T. Novel devices for implant based breast reconstruction: is the use of meshes to support the lower pole justified in terms of benefits? A review of the evidence. Ecancer 2018; 12: 796. doi:10.3332/ ecancer.2018.796

[36] Dieterich M, Paepke S, Zwiefel K et al. Implant-based breast reconstruction using a titanium-coated polypropylene mesh (TiLOOP Bra): a multicenter study of 231 cases. Plast Reconstr Surg 2013; 132: 8e-19e

[37] Rezai M, Strauß S, Kimmig R et al. Risk-reducing, conservative mastectomy - analysis of surgical outcome and quality of life in 272 implantbased reconstructions using Tiloop ${ }^{\circledR}$ Bra versus autologous corial flaps. Gland Surg 2016; 5: 1-8 
[38] Dieterich M, Stubert ], Gerber B et al. Biocompatibility, cell growth and clinical relevance of synthetic meshes and biological matrixes for internal support in implant-based breast reconstruction. Arch Gynecol Obstet 2015; 291: 1371-1379

[39] Derderian CA, Karp NS, Choi M. Wise pattern breast reconstruction: Modification using AlloDerm and a vascularized dermal-subcutaneous pedicle. Ann Plast Surg 2009; 62: 528-532

[40] Gamboa-Bobadilla GM. Implant breast reconstruction using acellular dermis matrix. Ann Plast Surg 2006; 56: 22-25

[41] Gschwantler-Kaulich D, Schrenk P, Bjelic-Radisic V et al. Mesh versus acellular dermal matrix in immediate implant-based breast reconstruction - A prospective randomized trial. Eur J Surg Oncol 2016; 42: 665671

[42] Sigalove S, Maxwell PG, Sigalove Noemi M et al. Prepectoral implantbased breast reconstruction: Rationale, indications, and preliminary results. Plast Reconstr Surg 2017; 139: 287-294

[43] Paepke S, Ohlinger R, Klein E et al. Prepectoral implant placement in plastic-reconstructive surgery - a contribution to the discussion. Senologie 2018; 15: 115-119

[44] Paepke S, Klein E, Krol J et al. Subpectoral implants in oncoplastic-reconstructive breast surgery - habit or necessity? First experience with epipectoral implant positioning covered by acellular dermis and meshs. Jahrestagung der Association of British Breast Surgeons 2012
[45] Reitsamer R, Peintinger F. Prepectoral implant placement and complete coverage with porcine acellular dermal matrix: a new technique for direct-to-implant breast reconstruction after nipple-sparing mastectomy. J Plast Reconstr Aesthet Surg 2015; 68: 162-167. doi:10.1016/j. bjps.2014.10.012

[46] Vidya R, Masià J, Cawthorn S et al. Evaluation ofthe effectiveness of the prepectoral breast reconstruction with Braxon dermal matrix: First multicenter European report on 100 cases. Breast J 2017; 23: 670-676. doi:10.1111/tbj. 12810

[47] Cassella D, Calabrese C, Bianchi S et al. Subcutaneous tissue expander placement with synthetic titanium-coated mesh in breast reconstruction: long term results. PRS GlobalOpen. Breast 2015. doi:10.1097| GOX/.00000000000000549

[48] Casella D, Bernini M, Bencini L et al. TiLoop ${ }^{\circledR}$ Bra mesh used for immediate breast reconstruction: comparison of retropectoral and subcutaneous implant placement in a prospective single-institution series. Eur J Plast Surg 2014; 37: 599-604

[49] Paepke S, Kiechle M, Ankel C. Patient reported outcome measures (PROMs) in implant based mesh-supported breast reconstruction - early results of a multicentre prospective trial. Deutsche Gesellschaft für Senologie Vortrag (2015) 